\title{
Effect of Media and Temperature on the Growth and Sclerotial Formation of Macrophomina phaseolina (Tassi) Goid causing Root Rot of Castor
}

\author{
Harshil Parmar $^{1 *}$, H.J. Kapadiya ${ }^{1}$, C.M. Bhaliya ${ }^{1}$ and R.C. Patel ${ }^{2}$ \\ ${ }^{1}$ Department of Plant Pathology, Junagadh Agricultural University, \\ Junagadh- 362 001, Gujarat, India \\ ${ }^{2}$ Agriculture Experimental Station, Paria, Navsari Agricultural University, \\ Gujarat, India \\ *Corresponding author
}

\section{A B S T R A C T}

The effects of different culture media and temperature on mycelial growth and

Keywords

Cultural media,

Temperature,

M. phaseolina,

Castor root rot

Article Info

Accepted:

07 January 2018

Available Online:

10 February 2018 sclerotial formation of Macrophomina phaseolina (Tassi) Goid inciting agent of castor root rot were studied in vitro. Eight different solid and liquid media were tested for their effect on mycelial growth and sclerotial formation of test fungus. Among the solid media, potato dextrose agar $(90.00 \mathrm{~mm})$ and Richard's agar $(87.71 \mathrm{~cm})$ were the best for fungus growth as well as for sclerotial formation followed by Elliott's medium $(80.08 \mathrm{~cm})$. Whereas in liquid media, richard's agar $(862.00 \mathrm{mg})$ found excellent followed by potato dextrose agar $(824.33 \mathrm{mg})$ for best mycelial growth and sclerotial formation of the test fungus. Different temperatures were tested for suitable fungal growth and it was observed that temperature range of 25 to $35{ }^{\circ} \mathrm{C}$ found optimum for growth and sclerotial formation. Whereas $30{ }^{\circ} \mathrm{C}(79.44 \mathrm{~mm})$ was the ideal for the growth of the fungus. Identified suitable media could be used for growth and sclerotial formation study and temperature ranged could be used for epidemiological study.

\section{Introduction}

Among the non-edible annual group of oilseed crops, castor constitutes very important position in the oil seed economy throughout the world. India is the world's principal producer of castor and ranks first both in area and production. Gujarat, Andhra Pradesh, Rajasthan, Tamil Nadu, Karnataka, Madhya Pradesh, Uttar Pradesh, Maharashtra and Orissa are the major castor growing states in the country. Various factors are responsible for low productivity of castor among them diseases are major concerns. Root rot of castor caused by Macrophomina phaseolina (Tassi) Goid is the most serious fungal disease of this crop. The estimated yield loss due to the disease has been reported from $20 \%$ to $60 \%$ (Savalia et al., 2003).

In order to culture the fungi artificially, it is necessary to supply all essential nutrients needed for their growth and development. Similarly, suitable temperature is also important for growth and metabolic processes of fungi. Therefore, the experiments were 
carried out to know the effects of culture media and temperature on mycelial growth and sclerotial formation of M. phaseolina.

\section{Materials and Methods}

\section{Solid and liquid media}

Eight media i.e., potato dextrose agar, Czapek's dox agar, Richard's media, standard nutrient agar, Asthana and Hawker's agar, Elliott's media, Houston's media and Martin's rose bengal were used. These agar agar based sterilized media were poured into $9 \mathrm{~cm}$ diameter sterilized Petri plates@ 20 ml/plate. After solidification, $5 \mathrm{~mm}$ diameter culture block of nine days old pure culture of $M$. phaseolina was cut with the help of sterilized cork borer and placed in the centre of Petri plates. Three replications were kept for recording observations on colony diameter, sclerotial formation and colony character of the fungus. The Petri plates were incubated at room temperature $\left(28 \pm 2{ }^{0} \mathrm{C}\right)$ and observations were recorded after ten days of incubation.

All the solid media used in earlier section were used as broth media with the same ingredients only omitting agar agar. Similarly, $50 \mathrm{ml}$ of liquid media prepared in $150 \mathrm{ml}$ conical flask for each medium with four replications. Sterilized media containing flask were incubated with test fungus. Out of four replications, one replication was kept for counting sclerotial formation of fungus. The rest of the replications were kept for recording dry mycelium weight of the fungus, which were incubated at room temperature for a period of ten days. After incubation period, the mycelial mats were filtered through Whatman filter paper and the filter papers with mycelial mats were dried in an oven at 60 ${ }^{0} \mathrm{C}$ for 24 hours and dry weight of the mycelium was recorded till constant weight. Sclerotia count was recorded from fourth replication. The whole mycelial substrate was homogenized in $50 \mathrm{ml}$ sterilized distilled water with the help of homogenizer and substrate was filtered through muslin cloth. A drop of the filter was examined and the numbers of sclerotia were counted.

Sclerotial formations were counted in fungal culture suspensions under the microscope at low power (10x). The fungal culture suspension was prepared by vigorously shaking the $4 \mathrm{~mm}$ mycelial disc of the fungus in $10 \mathrm{ml}$ sterilized distilled water. The sclerotial count was grouped as: $-=$ absent; + $=1-4 ;++=5-8 ;+++=9-15$ and $++++=$ above 10 .

\section{Temperature}

The growth of $M$. phaseolina was tested at 10 , $15,20,25,30,35$ and $40{ }^{\circ} \mathrm{C}$. Sterilized potato dextrose agar was poured into $90 \mathrm{~mm}$ diameter sterilized Petri plates. After solidification, $5 \mathrm{~mm}$ disc from actively growing cultures were cut and inoculated to solidified Petri plates and incubated for 8 days in the incubator adjusted to required temperature levels. Each treatment was replicated thrice. After incubation period, radial growth and sclerotial formation from solid media were recorded.

\section{Results and Discussion}

The result presented in table 1 revealed that among all solid media tested, maximum mycelial growth was obtained in potato dextrose agar medium $(90 \mathrm{~mm})$, which was statically at par with Richard's agar medium $(87.71 \mathrm{~mm})$. The rest of the media viz., Elliott's medium $(80.08 \mathrm{~mm})$, Asthana and Hawker's medium (67.06 mm), standard nutrient $(64.89 \mathrm{~mm})$, Houston's medium $(53.88 \mathrm{~mm})$, martin's rose bengal $(50.00 \mathrm{~mm})$ and Czapek's medium (44.68 mm) were also supported good growth of the fungus $M$. 
phaseolina. Excellent sclerotial formation was observed in potato dextrose agar and richard's medium. Colony character and colour of substrate are also noted in table 1 . The present result supported by the finding of Mathukia (1982) who also obtained highest growth and sclerotial formation of $M$. phaseolina on potato dextrose agar followed by richard's medium, he also reported flat mycelial growth with white to dirty white mycelium colour in all media except elliott's media where it was pinkish. This result is also in agreement with finding of Jha and Dubey (2000).

In liquid media, maximum dry mycelial weight was recorded in richard's medium $(862.00 \mathrm{mg})$ which was significantly superior over rest of the broth media (Table 2). In order of merit, the next best media was potato dextrose medium $(824.33 \mathrm{mg}$ ) followed by asthana and hawker's medium (640.00 mg), elliott's medium (636.67 mg) and standard nutrient $(603.00 \mathrm{mg})$. While, Houston's medium $(503.00 \mathrm{mg})$, czapek's media (428.67 $\mathrm{mg}$ ) and martin's rose bengal $(382.43 \mathrm{~mm})$ were poor as it yield less dry mycelial yield. Abundant sclerotial formation was observed in potato dextrose agar and Richard's medium in both solid and liquid medium. The present results are in agreement with the results obtained by Tandel et al. (2012) who reported that among the various liquid media tested, higher dry mycelial weight was yielded in Richard's medium as compared to rest of media.

Table.1 Growth, sclerotial formation and colony character of M. phaseolina on solid media in vitro

\begin{tabular}{|c|c|c|c|c|}
\hline $\begin{array}{l}\text { Sr. } \\
\text { No }\end{array}$ & Agar Medium & $\begin{array}{c}\text { Colony } \\
\text { diameter }(\mathrm{mm})\end{array}$ & $\begin{array}{l}\text { Sclerotial } \\
\text { formation }\end{array}$ & $\begin{array}{c}\text { Colony character and colour of } \\
\text { substratum }\end{array}$ \\
\hline 1 & Potato dextrose agar & 90.00 & ++++ & $\begin{array}{l}\text { Slightly fluffy growth, mycelium } \\
\text { white and dark blackish } \\
\text { substratum }\end{array}$ \\
\hline 2 & Richard's agar media & 87.71 & ++++ & $\begin{array}{l}\text { Flat growth, mycelium white and } \\
\text { dark greenish brown substratum }\end{array}$ \\
\hline 3 & Elliott's media & 80.08 & + & $\begin{array}{l}\text { Flat pinkish white mycelium with } \\
\text { pinkish black substratum }\end{array}$ \\
\hline 4 & $\begin{array}{l}\text { Asthana and Hawker's } \\
\text { agar media }\end{array}$ & 67.06 & +++ & $\begin{array}{l}\text { Flat dirty white mycelium and } \\
\text { dark blackish substratum }\end{array}$ \\
\hline 5 & Standard nutrient agar & 64.89 & +++ & $\begin{array}{l}\text { Flat growth, mycelium white and } \\
\text { dark blackish substratum }\end{array}$ \\
\hline 6 & Houston's media & 53.88 & + & $\begin{array}{l}\text { Flat growth, mycelium dirty white } \\
\text { and dark brown substratum }\end{array}$ \\
\hline 7 & Martin's rose bengal & 50.00 & + & $\begin{array}{l}\text { Slightly fluffy milky white } \\
\begin{array}{l}\text { mycelium } \\
\text { substratum }\end{array}\end{array}$ \\
\hline 8 & Czapek's dox agar & 44.68 & + & $\begin{array}{l}\text { Slightly fluffy white mycelium } \\
\text { with black substratum }\end{array}$ \\
\hline & S. Em. \pm & \multicolumn{3}{|r|}{  } \\
\hline & C.D. at $5 \%$ & \multicolumn{3}{|l|}{4.52} \\
\hline & C.V. \% & \multicolumn{3}{|l|}{3.88} \\
\hline
\end{tabular}


Table.2 Growth and sclerotial formation of M. phaseolina on liquid media in vitro.

\begin{tabular}{|c|c|c|c|}
\hline Sr. No & Liquid medium & Dry mycelial weight (mg) & $\begin{array}{l}\text { Sclerotial } \\
\text { formation }\end{array}$ \\
\hline 1 & Richard's media & 862.00 & ++++ \\
\hline 2 & Potato dextrose agar & 824.33 & ++++ \\
\hline 3 & Asthana and hawker's agar media & 640.00 & +++ \\
\hline 4 & Elliott's media & 636.67 & +++ \\
\hline 5 & Standard nutrient agar & 603.00 & +++ \\
\hline 6 & Houston's media & 503.00 & ++ \\
\hline 7 & Czapek's dox agar & 428.67 & ++ \\
\hline 8 & Martin's rose Bengal & 382.43 & + \\
\hline & S. Em. \pm & \multicolumn{2}{|l|}{9.65} \\
\hline & C.D. at 5\% & \multicolumn{2}{|l|}{28.94} \\
\hline & C.V. $\%$ & \multicolumn{2}{|l|}{2.74} \\
\hline
\end{tabular}

Table.3 Growth and sclerotial formation of M. phaseolina at different temperature in vitro.

\begin{tabular}{|c|c|c|c|}
\hline $\begin{array}{c}\text { Sr. } \\
\text { No. }\end{array}$ & Temperature $\left.\mathbf{(}^{\mathbf{0}} \mathbf{C}\right)$ & Mean colony diameter $\mathbf{( m m})$ & Sclerotial formation \\
\hline $\mathbf{1}$ & $10^{0}$ & 25.16 & - \\
\hline $\mathbf{2}$ & $15^{0}$ & 29.47 & - \\
\hline $\mathbf{3}$ & $20^{0}$ & 48.71 & - \\
\hline $\mathbf{4}$ & $25^{0}$ & 73.76 & ++++ \\
\hline $\mathbf{5}$ & $30^{0}$ & 79.44 & ++++ \\
\hline $\mathbf{6}$ & $35^{0}$ & 63.49 & +++ \\
\hline $\mathbf{7}$ & $40^{0}$ & 29.51 & - \\
\hline & S. $\mathbf{E m} . \mathbf{\pm}$ & $\mathbf{1 . 4 2}$ & \\
\hline & C.D. at 5\% & $\mathbf{4 . 3 1}$ & \\
\hline & C.V. $\%$ & $\mathbf{4 . 9 2}$ \\
\hline
\end{tabular}

Temperature plays an important role in infection and disease development. Data presented in table 3 revealed that, maximum mean colony diameter of test fungus was recorded at temperature of $30{ }^{\circ} \mathrm{C}(79.44 \mathrm{~mm})$ which was significantly superior over all other temperature. Lowest mean colony diameter was obtained at temperatures of 10 ${ }^{0} \mathrm{C}(25.16 \mathrm{~mm})$ and $40{ }^{0} \mathrm{C}(29.51 \mathrm{~mm})$. In the present study, it was observed that temperature range of $25{ }^{\circ} \mathrm{C}$ to $35{ }^{\circ} \mathrm{C}$ can be recommended to obtain excellent fungal growth and sclerotial formation of $M$. phaseolina. The present result are in agreement with the results obtained by Bhargava (1965), Dhingra and Sinclair (1973) and Das (1988). Csondes et al., (2007) found most favourable temperature range was 25 to $35{ }^{\circ} \mathrm{C}$ for $M$. phaseolina isolates and mycelial growth of pathogen was very low at 10,15 and $40^{\circ} \mathrm{C}$ and did not form sclerotia. 
The present result indicate that potato dextrose agar media and Richard's medium in solid and liquid form found best in mycelial growth and sclerotia formation of $M$. phaseolina. Similarly, the test fungus grows well in temperature range of 25 to $30{ }^{0} \mathrm{C}$. Such information will be useful in different in vitro experiment of this fungus as well as in epidemiology study.

\section{Acknowledgement}

The authors are grateful to the Department of Plant Pathology, College of Agriculture, Junagadh Agricultural University for providing facilities to conduct this research.

\section{References}

Bhargava, S. M. 1965. Studies on the charcoal rot of potato. Phytopathology, 53(1): 3544.

Csondes, L.; Kadlicsko, S. and Gaborjanyi, R. 2007. Effect of different temperature and culture media on the growth of Macrophomina phaseolina. Bio Sci., 72(4):839-848.

Das, N. D. 1988. Effect of different source of carbon, nitrogen and temperature of the growth and sclerotial formation of Macrophomina phaseolina (Tassi) Goid causing root rot of castor. Indian $\mathrm{J}$. Pl. Pathol., 6(2): 97-98.

Dhingra, O. D. and Sinclair, J. B. 1973. Variation among isolates of $M$. phaseolina (R. bataticola) from some soybean plant. Phytopathology, 62: 1108.

Jha, A. K. and Dubey, S. K. 2000. Occurance of collar rot of okra in plateau region of Bihar. J. Res. Birsa Agril. Uni., 12(1): 6772.

Mathukia, R. G. 1982. Investigations on $M$. phaseolina (Tassi) Goid causing root rot and leaf blight of groundnut (Arachis hypogaea L.). M. sc. (Agri.) Thesis, Gujarat Agril. University, Sardarkrishinagar.

Savalia, R. L.; Khandhar, R. R. and Moradia, A. M. 2003. Screening of castor germplasm against root rot caused by Macrophomina phaseolina under sick plot. ISOR National Seminar: Stress Management in Oilseeds.

Tandel, D. H.; Sabalpara. A. N. and Patel, R. C. 2012. Evaluation of different solid and liquid media for the growth and sclerotial formation of Macrophomina phaseolina in vitro. The Bioscan, 7(4): 743-745.

\section{How to cite this article:}

Harshil Parmar, H.J. Kapadiya, C.M. Bhaliya and Patel, R.C. 2018. Effect of Media and Temperature on the Growth and Sclerotial Formation of Macrophomina phaseolina (Tassi) Goid causing Root Rot of Castor. Int.J.Curr.Microbiol.App.Sci. 7(02): 671-675. doi: https://doi.org/10.20546/ijcmas.2018.702.083 